\title{
Pengaruh Sosialisasi Perpajakan, Pemahaman Prosedur Perpajakan, Umur, Jenis Pekerjaan Terhadap Kepatuhan Wajib Pajak Orang Pribadi
}

\author{
Muhammad Faris Naufal ${ }^{1}$ \\ Putu Ery Setiawan ${ }^{2}$ \\ ${ }^{1}$ Fakultas Ekonomi dan Bisnis Universitas Udayana (Unud), Bali, Indonesia \\ email: faris.naufal29@gmail.com/ Telp :085858125915 \\ ${ }^{2}$ Fakultas Ekonomi dan Bisnis Universitas Udayana (Unud), Bali, Indonesia
}

\begin{abstract}
ABSTRAK
Melakukan semua kewajiban perpajakan dan menggunakan hak perpajakannya dengan tetap mengacu kepada peraturan perundang-undangan perpajakan yang berlaku. Penelitian ini bertujuan untuk mengetahui pengaruh sosialisasi perpajakan, pemahaman prosedur perpajakan, umur, jenis pekerjaan terhadap kepatuhan wajib pajak orang pribadi di Kantor Pelayanan Pajak Pratama Tabanan. Populasi dalam penelitian ini adalah seluruh wajib pajak orang pribadi di Kantor Pelayanan Pajak Pratama tabanan. Jumlah sampel yang digunakan dalam penelitian ini sebanyak 100 responden dihitung berdasarkan rumus Slovin dengan metode penentuan sampel adalah metode accidental sampling. Pengumpulan data dilakukan dengan menggunakan kuesioner. Teknik analisis data yang digunakan adalah analisis regresi linier berganda dengan variabel dummy. Hasil pengujian hipotesis ini menunjukkan bahwa variabel sosialisasi perpajakan dan pemahaman prosedur perpajakan berpengaruh positif terhadap kepatuhan wajib pajak orang pribadi di Kantor Pelayanan Pajak Pratama Tabanan, sedangkan variabel umur dan jenis pekerjaan memiliki pengaruh negatif terhadap kepatuhan wajib pajak orang pribadi di Kantor Pelayanan Pajak Pratama Tabanan.

Kata kunci: sosialisasi perpajakan, pemahaman prosedur perpajakan, kepatuhan wajib pajak
\end{abstract}

\begin{abstract}
This study aims to determine the effect of taxation socialization, understanding of tax procedures, age, type of work to the taxpayer compliance of individuals in the Tax Office Pratama Tabanan. Population in this research is all individual taxpayer in Tax Office Primary tabanan. The number of samples used in this study as many as 100 respondents calculated based on Slovin formula with the method of determining the sample is accidental sampling method. The data were collected by using questionnaires. Data analysis technique used is multiple linier regression analysis with dummy variable. The results of this hypothesis testing indicate that the variable of taxation socialization and understanding of tax procedure have a positive effect on taxpayer compliance of individual in Pratama Tabanan Tax Office, while the variable of age and type of work have a negative effect on taxpayer compliance of individual in Tax Office Pratama Tabanan.
\end{abstract}

Keywords: tax socialization, understanding tax procedure, taxpayer compliance

\section{PENDAHULUAN}

Pajak adalah iuran rakyat kepada kas negara berdasarkan Undang-undang (yang

dapat dipaksakan) dengan tiada mendapat jasa timbal (kontrapretasi) yang 
langsung dapat ditunjukkan dan yang digunakan untuk membayar pengeluaran umum. Jumlah pendapatan negara terbesar berasal dari sektor pajak. Hal tersebut dapat dilihat pada Tabel 1. tentang realisasi penerimaan negara yang berasal dari pajak dan jumlah penerimaan negara yang bukan berasal dari pajak menurut data dari Badan Pusat Statistik tahun 2018.

Tabel 1.

Realisasi Penerimaan Negara Tahun 2013-2016 (dalam milyar rupiah)

\begin{tabular}{lrcrcc}
\hline Tahun & \multicolumn{2}{c}{ Sumber Penerimaan } & & & Total \\
& Penerimaan Pajak & Penerimaan Bukan Pajak & \\
& Rupiah (Rp) & Persentase (\%) & Rupiah (Rp) & Persentase (\%) & \\
\hline 2013 & $1,077,306$ & 75.2 & 354,751 & 24.8 & $1,432,057$ \\
2014 & $1,146,865$ & 74.2 & 398,590 & 25.8 & $1,545,455$ \\
2015 & $1,240,418$ & 82.9 & 255,628 & 17.1 & $1,496,046$ \\
2016 & $1,283,673$ & 83.0 & 262,483 & 17.0 & $1,546,156$ \\
\hline
\end{tabular}

Sumber: Statistik Indonesia 2018

Berdasarkan Tabel 1 di atas tampak bahwa penerimaan sektor pajak lebih besar jumlahnya dibandingkan penerimaan dari sektor non pajak. Hal tersebut membuktikan bahwa kontribusi dari penerimaan pajak sangat penting sebagai sumber penerimaan negara.

Menyadari peran pajak sangat penting, peningkatan penerimaan pajak menjadi tuntutan pemerintah. Perbaikan- perbaikan dan perubahan mendasar dari waktu ke waktu dalam segala aspek perpajakan terus dilakukan demi memaksimalkan penerimaan pajak. Salah satu cara yang dilakukan adalah dengan memberlakukannya system pemungutan pajak dengan self assessment system yang artinya sistem ini memberikan kewenangan kepada wajib pajak untuk menghitung, membayar, serta melaporkan sendiri jumlah pajak yang terutang sebagaimana yang sudah diatur dalam peraturan perpajakan yang berlaku yaitu 
Undang-undang Nomor 28 Tahun 2007 tentang Ketentuan Umum dan Tata Cara Perpajakan. Saat ini, bila pajak tidak dipatuhi dan dipenuhi pembayarannya oleh wajib pajak maka pemerintahan tidak dapat berjalan dengan baik (Hammar et al, 2005). Demi memaksimalkan penerimaan pajak, selain dibutuhkan peran dari Dirjen Pajak, dibutuhkan pula peran aktif dari wajib pajak. Kepatuhan wajib pajak menjadi salah satu modal kunci untuk keberhasilan self assessment system.

Keberhasilan pelaksanaan self assessment system sangat terkait dengan karakteristik seorang wajib pajak. Karakteristik wajib pajak dapat dilihat dari gender (jenis kelamin), latar belakang pekerjaan, dan tingkat pendidikan. Berdasarkan penelitian yang dilakukan oleh Jackson and Milliron (1986) di bidang kepatuhan perpajakan dari tahun 1974 sampai dengan 1985, disimpulkan ada 14 variabel yang memengaruhi perilaku kepatuhan perpajakan, yakni umur, jenis kelamin, pendidikan, tingkat penghasilan, sumber penghasilan, jenis pekerjaan, pengaruh pasangan/keluarga, etika, keadilan, kompleksitas, hubungan dengan otoritas pajak, sanksi, kemungkinan diaudit, dan tarif pajak.

Fenomena yang terjadi saat ini adalah masih banyaknya wajib pajak yang belum memahami akan peraturan serta kegunaan pajak. Hal ini dapat menurunkan jumlah penerimaan pajak serta tingkat kepatuhan wajib pajak. Keengganan wajib pajak untuk membayar pajak bisa berkurang apabila wajib pajak mengetahui dan memahami peraturan perpajakan serta kegunaan pajak dengan baik dan benar. Membangun kepatuhan wajib pajak merupakan salah satu cara yang dapat dilakukan untuk semakin memaksimalkan penerimaan negara dari sektor perpajakan. 
Menteri Keuangan (Menkeu) Sri Mulyani Indrawati pada konfrensi pers Anggaran Pendapatan dan Belanja Negara Perubahan (APBNP) di gedung Djuanda I, Jakarta yang dilaksanakan pada Rabu 20 Desember 2017 menyatakan bahwa penerimaan negara dari sektor perpajakan pada tahun 2017 diperkirakan tidak tercapai. Realisasi dalam Anggaran Pendapatan dan Belanja Negara Perubahan (APBNP) 2017 per 15 Desember khusus penerimaan pajak mencapai Rp1.058,4 triliun atau 82,5 persen dari target $\mathrm{Rp} 1.283$ triliun. Proses menuju kepatuhan yang tinggi merupakan upaya yang berkelanjutan. Semakin tinggi tingkat kepatuhan pajak, maka akan memperbesar basis perpajakan dan ini berakibat akan semakin besar penerimaan pajak yang dapat dihimpun.

Kepatuhan wajib pajak mencakup kepatuhan mencatat atau membukukan transaksi usaha, kepatuhan melaporkan kegiatan usaha sesuai peraturan yang berlaku, serta kepatuhan terhadap semua aturan perpajakan lainnya. Di antara ketiga jenis kepatuhan tersebut, yang paling mudah diamati adalah kepatuhan melaporkan kegiatan usaha, karena seluruh wajib pajak berkewajiban menyampaikan laporan kegiatan usahanya setiap bulan dan/atau setiap tahun dalam bentuk menyampaikan Surat Pemberitahuan (SPT) dalam setiap masa atau tahunannya. Beberapa wajib pajak mempunyai kepatuhan yang buruk dengan tidak membuat dan menyampaikan laporan kegiatan usaha secara periodik secara benar, lengkap dan jelas, baik laporan bulanan atau masa maupun tahunan. Lebih memprihatinkan adalah wajib pajak semacam ini berjumlah paling banyak dari seluruh wajib pajak terdaftar. Patut menjadi perhatian lebih serius bagi Ditjen Pajak agar masalah ini bisa diatasi dan diawasi secara lebih. 
Wajib pajak yang masuk kategori patuh adalah wajib pajak yang mengisi formulir SPT dengan benar, menghitung pajak dengan benar, membayar pajak dan melaporkan pajak tepat pada waktunya. Kondisi perpajakan yang menuntut keikutsertaan aktif wajib pajak dalam menyelenggarakan perpajakannya membutuhkan kepatuhan wajib pajak yang tinggi, yaitu kepatuhan dalam pemenuhan kewajiban perpajakan yang sesuai dengan kebenarannya. Kepatuhan memenuhi kewajiban perpajakan secara sukarela merupakan tulang punggung dari self assessment system, dimana wajib pajak bertanggung jawab menetapkan sendiri kewajiban perpajakan kemudian secara akurat dan tepat waktu dalam membayar dan melaporkan pajaknya.

Sosialisasi merupakan hal yang tidak terpisahkan dalam upaya peningkatan jumlah wajib pajak. Kegiatan penyuluhan pajak ini juga memiliki andil yang besar dalam menyukseskan peningkatan penerimaan perpajakan. Sebagaimana dinyatakan Direktur Jendral Pajak bahwa menanamkan pengertian dan pemahaman tentang pajak bisa diawali dari lingkungan keluarga sendiri yang terdekat, melebar kepada tetangga, lalu dalam forum-forum tertentu dan ormasormas tertentu melalui sosialisasi. Tingginya intensitas informasi yang diterima oleh masyarakat, dapat secara perlahan merubah pola pikir masyarakat tentang pajak ke arah yang positif (Susanto, 2012).

Pemahaman wajib pajak terhadap peraturan perpajakan adalah cara wajib pajak dalam memahami peraturan perpajakan yang telah ada. Wajib pajak yang tidak paham akan peraturan perpajakan maka cenderung menjadi wajib pajak yang tidak taat (Hardiningsih, 2011). Ketidakpahaman mengenai prosedur pajak 
seringkali membuat masyarakat tidak mendaftarkan diri sebagai Wajib Pajak dikarenakan masyarakat tidak mengetahui cara untuk mndaftarkan diri sebagai Wajib Pajak. Ketidaktahuan akan prosedur pajak juga dapat membuat Wajib Pajak tidak menjalankan kewajiban pajaknya sesuai dengan prosedur perpajakan yang berlaku. Prosedur pajak merupakan serangkaian cara yang dilalui dalam melakukan kewajiban pajak. Jika Wajib Pajak tidak memahami prosedur pajak, hal ini dapat menimbulkan permasalahan dalam menjalankan kewajiban pajak bagi Wajib Pajak yang bersangkutan. Wajib pajak yang memiliki pemahaman perpajakan yang baik, diharapkan tingkat kepatuhan dalam perpajakan juga semakin tinggi, wajib pajak juga akan semakin mengetahui peran dan manfaat dari pajak yang dibayarkan, dan diharapkan dapat meningkatkan kemauan wajib pajak dalam membayar pajak.

Faktor umur juga merupakan salah satu faktor yang dapat mempengaruhi kepatuhan wajib pajak. Wajib pajak yang memiliki usia lebih tua biasanya memiliki sikap lebih taat terhadap pajak dibandingkan wajib pajak yang berusia muda. Perbedaan generasi menyebabkan wajib pajak yang lebih muda lebih berani dalam mengambil risiko dan sikap kurang taat terhadap pajak. Wajib pajak yang lebih muda, lebih berani mengambil risiko, kurang sensitif terhadap hukuman, dan reflek sosial. Hasil penelitian yang berbeda menyimpulkan bahwa umur berpengaruh terhadap kepatuhan perpajakan namun berkorelasi negatif, artinya orang yang lebih muda lebih patuh dibandingkan dengan orang yang lebih tua. 
Terdapat beberapa jenis pekerjaan yang ada, dan akan makin bertambah lagi seiring dengan perkembangan zaman. Penghasilan dari pekerjaan seseorang merupakan obyek potensial bagi perpajakan di Indonesia, baik itu dari Pegawai Negri Sipil (PNS), TNI, Polri, pegawai swasta, wirausaha maupun profesi. Penghasilan yang mereka peroleh merupakan obyek pajak penghasilan dan harus dipotong oleh pemerintah. Menurut Resmi (2009) pegawai adalah setiap orang pribadi yang melakukan pekerjaan berdasarkan perjanjian atau kesepakatan kerja baik tertulis maupun tidak tertulis, termasuk yang melakukan pekerjaan dalam jabatan negri atau badan usaha milik negara atau badan usaha milik daerah.

Penelitian ini dilakukan di Kota Tabanan yang berlokasi di Kantor Pelayanan Pajak Pratama Tabanan. Pentingnya kepatuhan wajib pajak dalam hal perpajakan serta tingkat kepatuhan wajib pajak orang pribadi di KPP Pratama Tabanan yang mengalami fluktuasi beberapa tahun terakhir, menjadi alasan peneliti melakukan penelitian di KPP Pratama Tabanan. Berikut pada Tabel 1.2 data mengenai tingkat kepatuhan WPOP di KPP Pratama Tabanan periode 20132016:

Tabel 2.

Tingkat Kepatuhan WPOP di KPP Pratama Tabanan Periode 2013-2016

\begin{tabular}{ccrrrr}
\hline No. & Tahun & $\begin{array}{c}\text { WPOP } \\
\text { Terdaftar }\end{array}$ & WPOP Efektif Wajib Pajak Orang Pribadi & $\begin{array}{c}\text { Kepatuhan (\%) } \\
\text { yang Patuh }\end{array}$ & \\
\hline 1 & 2013 & 82,746 & 62,935 & 39,531 & 47.77 \\
2 & 2014 & 90,220 & 70,395 & 43,028 & 47.69 \\
3 & 2015 & 98,211 & 78,375 & 37,319 & 37.99 \\
4 & 2016 & 105,973 & 86,135 & 45,996 & 43.40 \\
\hline
\end{tabular}

Sumber: KPP Pratama Tabanan, 2017 
Berdasarkan Tabel 2, dapat diketahui bahwa persentase kepatuhan WPOP yang terdaftar di KPP Pratama Tabanan mengalami fluktuasi. Tingkat kepatuhan pelaporan SPT di KPP Pratama Tabanan pada Tahun 2013 sebesar 47,77 persen, kemudian pada Tahun 2014 menurun menjadi 47,69 persen, mengalami penurunan lagi pada Tahun 2015 menjadi 37,99 persen, dan meningkat lagi pada Tahun 2016 sebesar 43,40 persen.

Penelitian sebelumnya tentang faktor yang dapat mempengaruhi kepatuhan wajib pajak. Penelitian yang dilakukan oleh Ardianto pada tahun 2013 tentang "Pengaruh Sosialisasi Perpajakan dan Pemahaman Prosedur Perpajakan Terhadap kepatuhan Wajib pajak PBB", memperoleh hasil bahwa sosialisasi dan pemahaman prosedur perpajakan berpengaruh positif terhadap kepatuhan wajib pajak. Penelitian oleh Al-Mamun et al (2014) tentang "Pengaruh Faktor Demografi Terhadap Sikap dan Perilaku Kepatuhan Wajib Pajak”, memperoleh hasil bahwa faktor demografi seperti umur, jenis kelamin, pendapatan berpengaruh terhadap kepatuhan pajak.

Kepatuhan wajib pajak dilihat dari faktor Behavioral Beliefs (keyakinan perilaku) bahwa wajib pajak mempunyai keyakinan membayar pajak tidak merugikan, dan juga pajak digunakan untuk pengeluaran serta pembangunan negara, maka dengan sukarela wajib pajak membayar pajaknya. Apabila kepatuhan wajib pajak dilihat dari faktor Normative Beliefs, adanya peraturan yang mengatur tentang perpajakan serta adanya dukungan dari keluarga dan temannya jika pajak diselenggarakan untuk keberlangsungan negara memberikan keyakinan dan kesadaran pada wajib pajak untuk membayar pajak. Apabila dilihat 
ISSN: 2302-8556

E-Jurnal Akuntansi Universitas Udayana Vol.25.1.Oktober (2018): 241-271 DOI: https://doi.org/10.24843/EJA.2018.v25.i01.p10

dari faktor Control Beliefs, adanya fasilitas pelayanan dan administrasi yang tidak berbelit - belit memudahkan wajib pajak dalam proses membayar serta melaporkan pajak menimbulkan presepsi wajib pajak jika membayar pajak itu mudah dan tidak merugikan wajib pajak.

Reason action theory mengatakan ada dua faktor penentu intensi yaitu sikap pribadi dan norma subjektif. Sikap merupakan evaluasi positif atau negatif individu terhadap perilaku tertentu. Sedangkan norma subjektif adalah persepsi seseorang terhadap tekanan sosial untuk melakukan atau tidak melakukan perilaku tertentu. Ajzen berpendapat bahwa reason action theory belum dapat menjelaskan tingkah laku yang tidak sepenuhnya berada di bawah kontrol seseorang, karena itu dalam theory of planned behavior Ajzen menambahkan satu faktor yang menentukan intensi yaitu perceived behavioral control. Perceived behavioral control merupakan persepsi individu terhadap kontrol yang dimilikinya sehubungan dengan perilaku tertentu (Ajzen, 2005). Faktor ini menurut Ajzen mengacu pada persepsi individu mengenai mudah atau sulitnya memunculkan tingkah laku tertentu dan diasumsikan merupakan refleksi dari pengalaman masa lalu dan juga hambatan yang diantisipasi. Menurut Ajzen (2005) ketiga faktor ini yaitu attitude, subjective norm, dan perceived behavioral control dapat memprediksi intensi individu dalam melakukan perilaku tertentu.

Semakin individu merasakan banyak faktor pendukung dan sedikit faktor penghambat untuk dapat melakukan suatu perilaku, maka individu akan cenderung mempersepsikan diri mudah untuk melakukan perilaku tersebut. Sebaliknya, semakin sedikit individu merasakan faktor pendukung dan banyak 
faktor penghambat untuk dapat melakukan suatu perilaku, maka individu akan cenderung mempersepsikan diri sulit untuk melakukan perilaku tersebut (Ajzen, 2006).

Menurut Siti Resmi (2011) Pajak adalah iuran rakyat kepada kas negara (peralihan kekayaan dari sektor pertukaran ke sektor pemerintah) berdasarkan undang-undang (dapat dipaksakan) dengan tiada mendapat jasa timbal balik (kontrapretasi) yang langsung dapat ditunjukan dan digunakan untuk membiayai pengeluaran umum.

Menurut Ilyas (2010) Pajak adalah iuran kepada negara (yang dapat digunakan) yang terutang oleh yang wajib membayarnya menurut peraturanperaturan dengan tidak mendapatkan timbale balik, yang langsung dapat ditunjuk, dan yang digunakan untuk membiayai pengeluaran-pengeluaran umum berhubung dengan tugas negara untuk penyelenggaraan pemerintah.

Pada literatur pajak, sering disebutkan pajak mempunyai dua fungsi, yaitu fungsi budgetair dan fungsi regulerend. Namun dalam perkembangannya, fungsi pajak tersebut dapat dikembangkan dan ditambah dua fungsi lagi, yaitu fungsi demokrasi dan fungsi redistribusi (Ilyas dan Burton, 2013). 1) Fungsi budgetair adalah fungsi yang terletak di sektor publik, yaitu fungsi untuk mengumpulkan uang pajak sebanyak-banyaknya sesuai dengan undang-undang berlaku yang pada waktunya akan digunakan untuk membiayai pengeluaran-pengeluaran negara, yaitu pengeluaran rutin dan pengeluaran pembangunan dan bila ada sisa (surplus) akan digunakan sebagai tabungan pemerintah untuk investasi pemerintah. 2) Fungsi regurelend adalah fungsi bahwa pajak-pajak tersebut akan digunakan 
sebagai suatu alat untuk mencapai tujuan-tujuan tertentu yang letaknya di luar bidang keuangan. Fungsi ini umumnya dapat dilihat pada sektor swasta. 3) Fungsi demokrasi adalah suatu fungsi yang merupakan salah satu penjelmaan atau wujud sistem gotong royong, termasuk kegiatan pemerintahan dan pembangunan demi kemaslahatan manusia. 4) Fungsi redistribusi adalah fungsi yang lebih menekankan pada unsur pemerataan dan keadilan dalam masyarakat.

Wajib pajak menurut Pasal 1 ayat 2 Undang-undang Nomor 16 Tahun 2009 tentang Ketentuan Umum dan Tata Cara Perpajakan adalah orang pribadi atau badan, meliputi pembayar pajak, pemotong pajak dan pemungut pajak, yang mempunyai hak dan kewajiban perpajakan sesuai dengan ketentuan peraturan perundang-undang perpajakan. Wajib pajak dapat dibedakan atas dua, yaitu: 1) Wajib Pajak Orang Pribadi. Orang pribadi yang menurut ketentuan peraturan perundang-undangan perpajakan ditentukan untuk melakukan kewajiban perpajakan. Surat Edaran Dirjen Pajak Nomor SE - 18/PJ/2011 menjelaskan pihak-pihak yang dimaksud sebagai wajib pajak orang pribadi, yaitu meliputi: a) WP orang pribadi Karyawan yaitu WP orang pribadi yang hanya menerima/memperoleh penghasilan dari satu atau lebih pemberi kerja atau penghasilan lainnya selain dari usaha/pekerjaan bebas. b) WP orang pribadi non karyawan yaitu WP orang pribadi yang menerima/memperoleh penghasilan dari usaha/pekerjaan bebas atau penghasilan lainnya. WP orang pribadi non karyawan ini termasuk juga WP orang pribadi karyawan yang menerima/memperoleh penghasilan dari usaha/pekerjaan bebas. 2) Wajib Pajak Badan. Sekumpulan orang atau modal yang merupakan kesatuan baik yang melakukan usaha maupun 
yang tidak melakukan usaha yang meliputi Perseroan Terbatas, Perseroan Komanditer, Perseroan lainnya, BUMN atau BUMD dengan nama dan dalam bentuk apapun, Firma, Kongsi, Koperasi, Dana Pensiun, Persekutuan, Perkumpulan, yayasan, organisasi massa, organisasi sosial politik, atau organisasi lainnya, lembaga dan bentuk badan lainnya, termasuk kontrak investasi kolektif dan bentuk usaha tetap.

Menurut Manurung (2013), kepatuhan pajak merupakan fenomena yang sangat kompleks yang dilihat dari banyak perspektif. Kepatuhan wajib pajak merupakan pemenuhan kewajiban perpajakan yang dilakukan oleh pembayar pajak dalam rangka memberikan kontribusi bagi pembangunan negara yang diharapkan didalam pemenuhannya dilakukan secara sukarela (Tryana, 2013). Ketidakpatuhan perpajakan merupakan masalah yang dihadapi oleh semua otoritas pajak. Penjelasan dan pengelompokan pola dan perilaku ketidakpatuhan perpajakan wajib pajak dan menemukan cara yang paling tepat untuk mengurangi tingkat ketidakpatuhan menjadi hal paling penting bagi otoritas perpajakan (Andreoni et al, 1998)

Pengertian kepatuhan wajib pajak Rahayu (2010), menyatakan bahwa kepatuhan perpajakan merupakan suatu keadaan dimana wajib pajak memenuhi semua kewajiban perpajakan dan melaksanakan hak perpajakannya. Kepatuhan wajib pajak dilihat dari kepatuhan wajib pajak dalam mendaftarkan diri, melaporkan Surat pemberitahuan, perhitungan dan pembayaran pajak terutang, serta dalam pembayaran tunggakan. Pengertian kepatuhan pajak menurut James 
dan Alley (2004), yaitu wajib pajak bersedia melakukan kewajibannya tanpa paksaan dalam membayar pajak berdasarkan peraturan yang berlaku.

Menurut Torgler (2005) salah satu masalah yang besar dan serius bagi para pembuat dan pengamat kebijakan ekonomi adalah meningkatkan kepatuhan wajib pajak. Kepatuhan yang tidak meningkat akan mengancam upaya pemerintah untuk meningkatkan kesejahteraan masyarakat (Gerald, 2009). Kepatuhan wajib pajak merupakan faktor penting dalam memperoleh pajak, perlu dipelajari secara intesif faktor-faktor yang mempengaruhi kepatuhan wajib pajak (Savitri dan Musfialdy, 2016).

Kepatuhan dalam wajib pajak dapat dikatakan sebagai kepatuhan dalam persyaratan pelaporan pajak dimana wajib pajak mengajukan dan melaporkan kewajibannya sesuai dengan peraturan yang berlaku (Devos, 2009). Jika sejumlah wajib pajak patuh dalam membayar dan melaporkan SPT Pajak Tahunan, rasio kepatuhan pajak akan meningkat (Nurhayati et al, 2015). Kepatuhan juga akan meningkat ketika seseorang menerima manfaat pelayanan publik yang baik dari pembayaran pajak (Nicoleta, 2011). Kepatuhan perpajakan mengacu pada kesediaan individu untuk bertindak sesuai dengan hukum dan peraturan pajak tanpa didahului penegakan hukum (James dan Alley, 2002).

Kepatuhan wajib pajak dapat diukur dari pemahaman terhadap semua ketentuan peraturan perundang-undangan perpajakan, mengisi formulir dengan lengkap dan jelas, menghitung jumlah pajak yang terutang dengan benar, membayar dan melaporkan pajak yang terutang tepat pada waktunya (Adiasa, 2013). 
Kegiatan penyuluhan pajak memiliki peranan dan andil yang cukup peting dalam mensosialisasikan pajak ke seluruh wajib pajak. Adanya kegiatan sosialisasi ini diharapkan dapat meningkatkan kepatuhan wajib pajak baik wajib pajak badan maupun wajib pajak orang pribadi dalam rangka meningkatkan jumlah penerimaan Negara. Berbagai media diharapkan mampu menggugah kesadaran masyarakat untuk patuh terhadap pajak dan membawa pesan moral terhadap pentingnya pajak bagi Negara (Winerungan, 2013). Kurangnya sosialisasi dari pemerintah kepada warga negara tentang perpajakan dapat mengakibatkan mereka kurang paham dan mengetahui apa sebenarnya manfaat utama dari pajak yang dibayarkan. Penyuluhan melalui berbagai media seperti media cetak, elektronik, spanduk, serta berbagai seminar pajak yang dilakukan Direktur Jendral Pajak diharapkan dapat membawa pesan moral terhadap pentingnya pajak bagi negara dan bukan hanya dapat meningkatkan pengetahuan wajib pajak dan membantu wajib pajak yang kurang paham tentang peraturan perpajakan yang baru, tetapi juga diharapkan dapat meningkatkan kepatuhan dari wajib pajak sehingga secara otomatis penerimaan pajak juga akan meningkat sesuai dengan target penerimaan yang ditetapkan.

Program-program yang telah dilakukan Direktorat Jenderal Pajak berkaitan dengan kegiatan penyuluhan tersebut antara lain dengan mengadakan seminar-seminar ke berbagai profesi, dan pelatihan baik untuk pemerintah maupun swasta, memasang spanduk yang bertemakan pajak, memasang iklan layanan masyarakat di berbagai stasiun televisi, mengadakan acara tax goes to campuss yang diisi dengan berbagai acara yang menarik mulai dari debat pajak 
sampai dengan seminar pajak dimana acara tersebut bertujuan guna menimbulkan pemahaman tentang pajak ke mahasiswa yang dinilai sangat kritis, selain mahasiswa, pelajar juga perlu dibekali tentang dasar-dasar pajak melalui acara tax education road show, serta memberikan penghargaan terhadap wajib pajak patuh pada setiap Kantor Pelayanan Pajak.

Berbagai program tersebut juga ditunjang dengan sarana-sarana yang mengakomodasi harapan masyarakat agar merasa mudah, cepat, dan benar dalam melaksanakan kewajiban perpajakannya. Sarana-sarana penunjang tersebut diantaranya adanya website pajak yaitu www.pajak.go.id, www.ortax.org, dan www.pajakonline.com. Dari website-website tersebut wajib pajak dan masyarakat bisa memperoleh artikel-artikel pajak, mengetahui perkembangan perpajakan di Indonesia, dan memperoleh informasi mengenai peraturan-peraturan perpajakan.

Menurut Sadiman (2010), yang dimaksud dengan pemahaman adalah suatu kemampuan seseorang dalam mengartikan, menafsirkan, menerjemahkan, atau menyatakan sesuatu dengan caranya sendiri tentang pengetahuan yang pernah diterimanya.

Pemahaman wajib pajak terhadap peraturan perpajakan adalah cara wajib pajak dalam memahami peraturan perpajakan yang telah ada. Wajib pajak yang tidak paham akan peraturan perpajakan maka cenderung menjadi wajib pajak yang tidak taat (Hardiningsih, 2011).

Ketidakpahaman mengenai prosedur pajak seringkali membuat masyarakat tidak mendaftarkan diri sebagai Wajib Pajak dikarenakan masyarakat tidak mengetahui cara untuk mndaftarkan diri sebagai Wajib Pajak. Ketidaktahuan akan 
prosedur pajak juga dapat membuat Wajib Pajak tidak menjalankan kewajiban pajaknya sesuai dengan prosedur perpajakan yang berlaku. Prosedur pajak merupakan serangkaian cara yang dilalui dalam melakukan kewajiban pajak. Jika Wajib Pajak tidak memahami prosedur pajak, hal ini dapat menimbulkan permasalahan dalam menjalankan kewajiban pajak bagi Wajib Pajak yang bersangkutan.

Wajib pajak yang memiliki pemahaman perpajakan yang baik, diharapkan tingkat kepatuhan dalam perpajakan juga semakin tinggi, wajib pajak juga akan semakin mengetahui peran dan manfaat dari pajak yang dibayarkan. Dengan begitu kemungkinan wajib pajak untuk melanggar peraturan pajak semakin kecil dan kemauan wajib pajak dalam membayar pajak juga semakin besar.

Pekerjaan adalah sebuah aktifitas antar manusia untuk saling memenuhi kebutuhan dengan tujuan tertentu, dalam hal ini pendapatan atau penghasilan. Penghasilan tersebut yang nantinya akan digunakan sebagai pemenuhan kebutuhan, baik ekonomi, psikis maupun biologis. Pekerjaan dalam arti luas adalah aktivitas utama yang dilakukan oleh manusia. Dalam arti sempit, istilah pekerjaan digunakan untuk suatu tugas atau kerja yang menghasilkan uang bagi seseorang. Jenis pekerjaan wajib pajak dalam penelitian ini mengacu pada penelitian sebelumnya oleh Amilin dan Fanny Yusronillah pada tahun 2009, dan dengan adanya Peraturan Pemerintah (PP) nomor 11 tahun 2017 soal alih status TNI dan Polri, yang mana peraturan ini merevisi PP Nomor 15 tahun 2011, maka jenis pekerjaan dalam penelitian ini dibagi menjadi beberapa bagian yaitu terdiri dari pegawai negeri sipil, pegawai swasta, profesi, wirausaha, TNI dan Polri. 
Sosialisasi merupakan hal yang penting dalam upaya peningkatan kepatuhan wajib pajak. Sosialisasi atau penyuluhan pajak merupakan kegiatan untuk lebih memberdayakan Wajib Pajak melalui pengertian, informasi, dan pembinaan supaya Wajib Pajak lebih memahami segala hal mengenai perpajakan sesuai peraturan perpajakan yang berlaku. Dengan adanya sosialisasi ini diharapkan masyarakat pada akhirnya menjadi masyarakat yang taat dan patuh dalam memenuhi kewajiban perpajakannya.

Kurangnya sosialisasi dari pemerintah kepada masyarakat yang masih awam tentang perpajakan dapat mengakibatkan masyarakat itu sendiri kurang memahami bagaiamana caranya melaksanakan kewajiban perpajakan dan mengetahui apa sebenarnya manfaat utama dari pajak yang dibayarkan yang pada akhirnya tidak melaksanakan kewajiban itu (Herryanto dan Toly, 2013). Sosialisasi tentang pentingnya pajak untuk masyarakat membuat masyarakat bisa sadar bahwa pajak adalah dari rakyat untuk rakyat, dari rakyat untuk kemakmuran rakyat. Sosialisasi ini isinya adalah menumbuhkan kesadaran masyarakat dan pengetahuan masyarakat akan pentingnya pajak bagi kemajuan negara.

Penelitian mengenai sosialisasi pajak bumi dan bangunan terhadap kepatuhan wajib pajak yang dilakukan oleh Donny Binambuni (2013) di Desa Karatung Kecamatan Nanusa Kabupaten Talaud, meyimpulkan bahwa sosialisasi pajak berpengaruh positif terhadap kepatuhan wajib pajak. Hasil penelitian tersebut dapat diketahui bahwa terdapat hubungan yang erat antara sosialisasi dengan kepatuhan wajib pajak yang berada di Kecamatan Nanusa. 
$\mathrm{H}_{1}$ : $\quad$ Sosialisasi perpajakan berpengaruh positif terhadap kepatuhan wajib pajak orang pribadi.

Pemahaman wajib pajak terhadap peraturan perpajakan adalah cara wajib pajak dalam memahami peraturan perpajakan yang telah ada. Tingkat pemahaman wajib pajak mengenai perpajakan menjadi sagatlah penting karena dapat mempengaruhi sikap dan perilaku wajib pajak akan kepatuhannya dalam melaksanakan kewajiban perpajakan (Hardiningsih, 2011). Walaupun wajib pajak berniat untuk melaksakan kewajiban pajaknya, wajib pajak tetap akan mengalami kesulitan dan cenderung tidak mampu dalam melaksanakan kewajiban perpajakannya karena kurangnya pemahaman mereka akan peraturan perpajakan yang berlaku hal ini akan mengakibatkan kepatuhan wajib pajak semakin rendah.

Tingkat pemahaman wajib pajak mengenai perpajakan menjadi sangatlah penting karena dapat mempengaruhi sikap dan perilaku wajib pajak akan kepatuhannya dalam melaksanakan kewajiban perpajakan. Pemahaman terhadap prosedur pajak yang mudah dipahami tidak berbelit-belit akan memudahkan wajib pajak untuk melakukan pembayaran serta pemenuhan kewajiban pajak lainnya. Tanpa adanya pemahaman prosedur pajak, wajib pajak akan merasa kesulitan dalam membayar pajak yang menyebabkan wajib pajak enggan patuh membayar pajak.

Hasil penelitian yang dilakukan Noviyanti (2015) dan Ardianto (2013) menyatakan pemahaman peraturan perpajakan berpengaruh positif terhadap kepatuhan wajib pajak. Hasil penelitian tersebut menyimpulkan bahwa semakin tinggi pemahaman perpajakan maka tingkat kepatuhan wajib pajak akan meningkat. 
$\mathrm{H}_{2}$ : Tingkat pemahaman prosedur perpajakan berpengaruh positif terhadap kepatuhan wajib pajak orang pribadi.

Menurut Jackson \& Milliron (1986), umur pembayar pajak adalah satu yang terpenting dari faktor yang menentukan kepatuhan pajak. Modal sosial individu seseorang akan semakin bertambah seiring dengan bertambahnya usia. Semakin dewasa seseorang, maka seseorang akan semakin terikat dalam suatu komunitas.

Semakin bertambah usia maka tingkat kepatuhan wajib pajak cenderung akan semakin rendah dalam memenuhi kewajiban perpajakannya di KPP Pratama Tabanan. Generasi muda cenderung memiliki kepatuhan yang lebih tinggi terhadap pajak, hal ini disebabkan karena generasi muda lebih mudah dan dapat menerima serta menyerap pembaruan peraturan perpajakan dan juga dengan adanya pelaporan dengan menggunakan sistem online juga dengan mudah di terima oleh wajib pajak yang lebih muda, sedangkan wajib pajak yang lebih tua cenderung kesulitan dalam menggunakan teknologi informasi dalam melaksanakan kewajiban perpajakannya.

Hasil penelitian terdahulu yang dilakukan oleh Al-Mamun et al. (2014) menyimpulkan bahwa umur berpengaruh terhadap kepatuhan perpajakan namun berkorelasi negatif, artinya wajib pajak yang lebih muda cenderung lebih patuh dibandingkan dengan wajib pajak dengan usia yang lebih tua.

$\mathrm{H}_{3}$ : Umur berpengaruh negatif terhadap kepatuhan wajib pajak orang pribadi.

Perbedaan pengenaan pajak atas penghasilan yang diterima oleh karyawan dengan wiraswasta dapat memengaruhi kepatuhan perpajakan wajib pajak. Pelaporan pihak ketiga atas pemotongan pajak juga akan mendorong kepatuhan 
perpajakan. Bagi karyawan, penghasilan yang diterimanya telah dipotong pajak oleh pemberi kerja. Jika seorang karyawan hanya bekerja di satu pemberi kerja bisa dikatakan bahwa dia patuh dalam hal pembayaran pajak karena pajak terutang atas penghasilannya sama dengan besarnya pemotongan pajak yang dilakukan pemberi kerja. Hal berbeda terjadi bagi wirausaha dimana banyak penghasilan mereka tidak dipotong pajak oleh pemberi penghasilan. Wirausaha memiliki biaya kepatuhan pajak yang tinggi sehingga mereka cenderung menggelapkan pajak (Lewis, 1982).

Setiap orang untuk melangsungkan kehidupannya melakukan pekerjaan masing-masing, bidang pekerjaan seseorang berbeda satu sama lain tergantung dari pilihan mereka akan pekerjaan tersebut serta latar belakang mereka. Jenis pekerjaan orang jika memerlukan pendidikan yang makin tinggi biasanya mereka mempunyai rasa tanggung jawab dan disiplin dalam memenuhi semua kewajibankewajibannya termasuk kewajiban membayar pajak. Jenis pekerjaan wajib pajak berpengaruh terhadap kepatuhan perpajakan dengan arah korelasi negatif. Penelitian tersebut menunjukkan bahwa responden yang bekerja sebagai pegawai negeri sipil lebih patuh dibandingkan dengan responden yang berwirausaha.

$\mathrm{H}_{4}$ : Jenis Pekerjaan berpengaruh terhadap kepatuhan wajib pajak orang pribadi.

\section{METODE PENELITIAN}

Lokasi penelitian ini dilakukan di Kantor Pelayanan Pajak Pratama Tabanan yang bertempat di Jalan Gatot Subroto Sanggulan, Tabanan, Bali. Kantor Pelayanan Pajak Pratama Tabanan dipilih sebagai lokasi penelitian karena tingkat kepatuhan wajib pajak di Kantor Pelayanan Pajak Pratama Tabanan mengalami fluktuasi 
dengan kecenderungan tingkat kepatuhan yang menurun. Populasi dalam penelitian ini adalah wajib pajak orang pribadi yang terdaftar di Kantor Pelayanan Pajak Pratama Tabanan. Untuk penelitian jumlah populasi yang terlalu banyak akan kita ambil untuk dijadikan sampel dengan harapan jumlah sampel yang kita ambil dapat mewakili populasi yang ada. Untuk menetukan ukuran sampel menggunakan rumus Slovin. Banyaknya sampel yang diambil pada penelitian ini adalah sebanyak 99,88 yang dibulatkan menjadi 100 wajib pajak orang pribadi.

Metode penentuan sampel dalam penelitian ini berdasarkan metode non probability sampling yaitu dengan menggunakan metode accidental sampling adalah teknik penentuan sampel berdasarkan kebetulan, yaitu siapa saja yang secara kebetulan bertemu dengan peneliti dapat digunakan sebagai sampel, bila orang tersebut dipandang cocok sebagai sumber data (Sugiyono, 2014:122).

Teknik analisis data yang dipergunakan untuk memecahkan masalah dalam penelitian ini adalah teknik analisis regresi linier berganda dengan variabel dummy. Analisis regresi linier berganda adalah untuk mengukur pengaruh antara lebih dari satu variabel bebas pada variabel terikat (Ghozali, 2013). Variabel dummy adalah variabel yang digunakan untuk mengkuantitatifkan variabel yang bersifat kualitatif (misal: jenis kelamin, ras, agama, perubahan kebijakan pemerintah, perbedaan situasi dan lain-lain).

\section{HASIL PENELITIAN DAN PEMBAHASAN}

Data penelitian yang digunakan dalam penelitian ini di peroleh melalui penyebaran kuesioner secara langsung di KPP Pratama Tabanan kepada para 
responden sejumlah 100 (seratus) orang yang merupakan wajib pajak orang pribadi yang terdaftar di KPP Pratama Tabanan.

Peneliti telah menyebarkan kuesioner sebanyak 100 eksemplar dengan tingkat pengembalian 100 persen dan tingkat pengembalian yang dapat dianalisis sebanyak 100 persen Terdapat beberapa karakteristik responden meliputi kepemilikan NPWP, jenis kelamin, Umur, dan jenis pekerjaan. Ringkasan mengenai karakteristik responden dapat dilihat pada tabel 3. Berikut

Tabel 3.

Karakteristik Responden

\begin{tabular}{|c|c|c|c|c|}
\hline No. & Variabel & Klasifikasi & Jumlah & Persentase (\%) \\
\hline \multirow{3}{*}{1.} & \multirow{3}{*}{ Jenis Kelamin } & Laki-Laki & 63 & 63,00 \\
\hline & & Perempuan & 37 & 37,00 \\
\hline & & Total & 100 & 100,00 \\
\hline \multirow{3}{*}{2.} & \multirow{3}{*}{ Status NPWP } & $\mathrm{Ya}$ & 100 & 100,00 \\
\hline & & Tidak & 0 & 0,00 \\
\hline & & Total & 100 & 100,00 \\
\hline \multirow{5}{*}{\multicolumn{2}{|c|}{ 3. Umur }} & $<36$ tahun & 44 & 44,00 \\
\hline & & $36-45$ tahun & 43 & 43,00 \\
\hline & & 46-55 tahun & 12 & 12,00 \\
\hline & & $>55$ tahun & 1 & 1,00 \\
\hline & & Total & 100 & 100,00 \\
\hline \multirow{7}{*}{\multicolumn{2}{|c|}{ 4. Pekerjaan }} & PNS & 27 & 27,00 \\
\hline & & Swasta & 32 & 32,00 \\
\hline & & Profesi & 7 & 7,00 \\
\hline & & Wirausaha & 34 & 34,00 \\
\hline & & TNI & 0 & 0,00 \\
\hline & & Polri & 0 & 0,00 \\
\hline & & Total & 100 & 100,00 \\
\hline
\end{tabular}

Sumber: Data diolah, 2018

Data karakteristik responden meliputi jenis kelamin, kepemilikan NPWP, umur, dan jenis pekerjaan yang diuraikan adalah jenis kelamin digunakan untuk mengetahui jenis kelamin dari para responden pada penelitian ini. Sebagian besar responden adalah laki-laki dengan persentase sebesar 63 persen, sedangkan sisanya sebesar 37 persen berjenis kelamin perempuan. Seluruh responden dalam penelitian ini merupakan status NPWP aktif. 
Umur digunakan untuk mengetahui usia dari para responden pada penelitian ini. Responden terbesar berasal dari kelompok umur $<36$ tahun sejumlah 44 persen, diikuti oleh kelompok umur 36-45 tahun sejumlah 43 persen, kemudian usia 46-55 tahun sejumlah 12 persen, sedangkan responden dengan usia lebih dari 55 tahun hanya berjumlah satu persen.

Responden dalam penelitian ini bekerja sebagai PNS sejumlah 27 persen, pegawai swasta sejumlah 32 persen, profesi sejumlah 7 persen, dan wirausaha sejumlah 34 persen.

Analisis ini menggunakan bantuan SPSS Statistics 21.0 dalam pengolahan. Hasil analisis model yang melibatkan seluruh variabel bebas pada model dapat dilihat pada tabel berikut:

Tabel 4.

Hasil Analisis Regresi Linear Berganda

\begin{tabular}{|c|c|c|c|c|c|}
\hline Model & $\begin{array}{c}\text { Unstandardize } \\
\text { B }\end{array}$ & Std. Error & $\begin{array}{c}\text { Standardized } \\
\text { Coefficients } \\
\text { Beta }\end{array}$ & $\mathbf{T}$ & Sig. \\
\hline (Constant) & 9.843 & 2.337 & & 4.211 & .000 \\
\hline $\mathrm{X} 1$ & .210 & .072 & .284 & 2.912 & .004 \\
\hline $\mathrm{X} 2$ & .292 & .080 & .295 & 3.658 & .000 \\
\hline $\mathrm{X} 3$ & -.283 & .136 & -.204 & -2.081 & .040 \\
\hline D1 & .183 & .247 & .086 & .741 & .460 \\
\hline D2 & -.215 & .360 & -.055 & -.596 & .553 \\
\hline D3 & -.674 & .248 & -.322 & -2.713 & .008 \\
\hline
\end{tabular}

Sumber: Data diolah, 2018

Berdasarkan hasil analisis yang disajikan pada Tabel 4., maka dapat disimpulkan bahwa masih terdapat variabel bebas yang tidak signifikan pada model terlihat dari nilai signifikan yang masih lebih besar dari 0,05. Selanjutnya, dilakukan analisis dengan algoritma stepwise untuk mendapatkan model terbaik, 
yang hanya menyertakan variabel yang telah signifikan. Hasil dari analisis regresi berganda dengan algoritma stepwise dapat dilihat pada tabel berikut:

Tabel 5.

Hasil Analisis Regresi Linear Berganda dengan Algoritma Stepwise

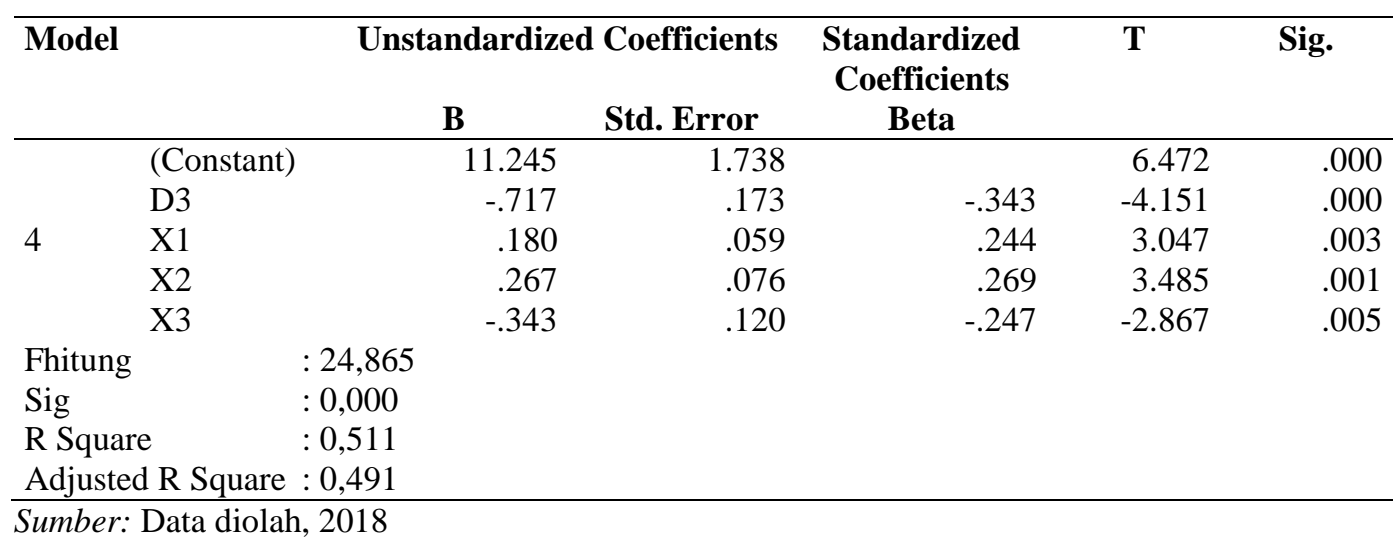

Hasil analisis dengan algoritma stepwise, menghasilkan empat model, dimana model terbaik adalah model terakhir atau model keempat, dimana seluruh variabel yang digunakan pada model telah signifikan. Berdasarkan tabel 5. dapat disusun persamaan regresi sebagai berikut:

$$
Y=11,245+0,180 X_{1}+0,267 X_{2}-0,343 X_{3}-0,717 D_{3}+e
$$

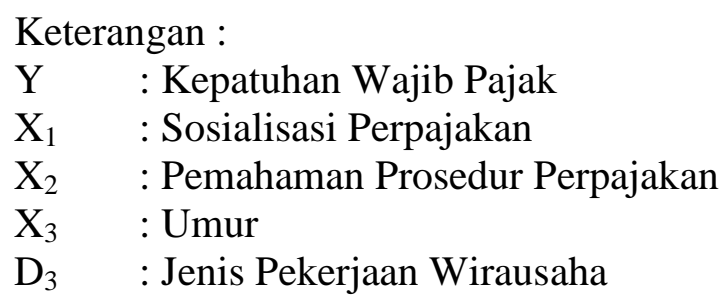

Koefisien determinasi $\left(\mathrm{R}^{2}\right)$ bertujuan untuk mengukur seberapa besar kemampuan model dalam menerangkan variasi dari variabel terikatnya. Berdasarkan uji hipotesis, koefisien determinasi dilihat dari besarnya nilai adjusted R-Square untuk mengetahui seberapa besar variabel bebas, yaitu 
sosialisasi perpajakan, pemahaman prosedur perpajakan, umur, dan jenis pekerjaan mempengaruhi tingkat kepatuhan wajib pajak. Berdasarkan tabel 5., nilai adjusted $R$-Square sebesar 0,491 memiliki arti 49,1\% tingkat kepatuhan wajib pajak dipengaruhi oleh sosialisasi perpajakn $\left(\mathrm{X}_{1}\right)$, pemahaman prosedur perpajakan $\left(\mathrm{X}_{2}\right)$, umur $\left(\mathrm{X}_{3}\right)$, dan jenis pekerjaan $\left(\mathrm{X}_{4}\right)$, sedangkan sisanya sebesar $50,9 \%$ dipengaruhi oleh faktor lainnya.

Berdasarkan hasil analisis data pada tabel 5. diperoleh nilai signifikansi t untuk variabel sosialisasi perpajakan sebesar 0,003 yang berarti lebih kecil dari nilai $\alpha=0,05$ dan nilai koefisien regresi sebesar 0,180 . Hal ini menunjukkan bahwa sosialisasi perpajakan berpengaruh positif terhadap kepatuhan wajib pajak orang pribadi di KPP Pratama Tabanan, dengan demikian hipotesis pertama dalam penelitian ini diterima. Sosialisasi perpajakan yang diberikan secara rutin maka tingkat kepatuhan wajib pajak juga akan semakin meningkat dalam memenuhi kewajiban perpajakannya di KPP Pratama Tabanan. Sosialisasi atau penyuluhan pajak merupakan kegiatan untuk lebih memberdayakan wajib pajak melalui pengertian, informasi, dan pembinaan supaya wajib pajak lebih memahami segala hal mengenai perpajakan sesuai peraturan perpajakan yang berlaku. Seringnya dilakukan sosialisasi perpajakan akan dapat membantu wajib pajak lebih memahami segala sesuatu tentang pajak dengan lebih baik sehingga dapat meningkatkan kepatuhan wajib pajak

Hasil penelitian ini sejalan dengan penelitian yang dilakukan oleh Donny Binambuni (2013), yang menyimpulkan bahwa sosialisasi perpajakan berpengaruh positif terhadap kepatuhan wajib pajak. Dengan adanya sosialisasi 
perpajakan diharapkan masyarakat pada akhirnya menjadi masyarakat yang taat dan patuh dalam memenuhi kewajiban perpajakannya.

Nilai signifikansi t untuk variabel pemahaman prosedur perpajakan yang terdapat pada hasil analisis data tabel 5. sebesar 0,001 yang berarti lebih kecil dari nilai $\alpha=0,05$ dan nilai koefisien regresi sebesar 0,267 . Hal ini menunjukkan bahwa pemahaman prosedur perpajakan berpengaruh positif terhadap kepatuhan wajib pajak orang pribadi di KPP Pratama Tabanan, dengan demikian hipotesis kedua dalam penelitian ini diterima. Semakin tinggi tingkat pemahaman prosedur perpajakan maka kepatuhan wajib pajak juga akan semakin meningkat dalam memenuhi kewajiban perpajakannya di KPP Pratama Tabanan. Seorang wajib pajak dapat berkonsultasi dengan seorang Account representative tentang prosedur perpajakan atau aturan perpajakan yang terbaru, dengan demikian dapat membuat wajib pajak lebih paham tentang perpajakan dan dapat meningkatkan kepatuhan wajib pajak dalam memenuhi kewajiban perpajakannya.

Hasil penelitian ini sejalan dengan penelitian yang dilakukan oleh Noviyanti (2015) dan Ardianto (2013) yang menyatakan pemahaman prosedur perpajakan berpengaruh positif terhadap kepatuhan wajib pajak. Jika wajib pajak memiliki tingkat pemahaman prosedur perpajakan yang tinggi maka dapat meningkatkan kepatuhan wajib pajak dalam memenuhi kewajiban perpajakannya.

Tabel 5. menunjukkan nilai signifikansi t untuk variabel umur sebesar 0,005 yang berarti lebih kecil dari nilai $\alpha=0,05$ dan nilai koefisien regresi sebesar -0,343. Hal ini menunjukkan bahwa umur berpengaruh negatif terhadap kepatuhan wajib pajak orang pribadi di KPP Pratama Tabanan, dengan demikian 
hipotesis ketiga dalam penelitian ini diterima.Semakin bertambah usia maka tingkat kepatuhan wajib pajak cenderung akan semakin rendah dalam memenuhi kewajiban perpajakannya di KPP Pratama Tabanan. Generasi muda cenderung memiliki kepatuhan yang lebih tinggi terhadap pajak, hal ini disebabkan karena generasi muda lebih mudah dan dapat menerima serta menyerap pembaruan peraturan perpajakan dan juga dengan adanya pelaporan dengan menggunakan sistem online juga dengan mudah di terima oleh wajib pajak yang lebih muda, sedangkan wajib pajak yang lebih tua cenderung kesulitan dalam menggunakan teknologi informasi dalam melaksanakan kewajiban perpajakannya.

Hasil penelitian ini sejalan dengan penelitian yang dilakukan oleh AlMamun et al. (2014) yang menyimpulkan bahwa umur berpengaruh terhadap kepatuhan wajib pajak namun berkorelasi negatif. Umur berpengaruh terhadap kepatuhan wajib pajak namun berkorelasi negatif memiliki arti bahwa seseorang wajib pajak yang lebih muda cenderung akan lebih patuh terhadap kewajiban perpajakannya dibandingkan dengan seorang wajib pajak yang lebih tua.

Berdasarkan hasil analisis data pada tabel 5. diperoleh nilai signifikansi t untuk variabel jenis pekerjaan sektor wirausaha sebesar 0,000 yang berarti lebih kecil dari nilai $\alpha=0,05$ dan nilai koefisien regresi sebesar $-0,717$. Hal ini menunjukkan bahwa jenis pekerjaan berpengaruh terhadap kepatuhan wajib pajak orang pribadi di KPP Pratama Tabanan, dengan demikian hipotesis keempat dalam penelitian ini diterima.

Responden yang bekerja sebagai Pegawai Negeri Sipil lebih patuh dibandingkan dengan responden yang sebagai wirausaha dalam memenuhi 
kewajiban perpajakannya di KPP Pratama Tabanan. Responden yang bekerja sebagai PNS atau karyawan swasta cenderung lebih patuh karena pajak penghasilan secara rutin dipotong oleh pemberi kerja atas penghasilan yang dibayarkan. Pemberi kerja umumnya mensyaratkan NPWP dalam pelamaran kerja. Beberapa pemberi kerja terutama instansi pemerintah mewajibkan pegawainya untuk menyampaikan SPT Tahunan tepat waktu dan memasukkan ketepatan waktu penyampaian SPT Tahunan ini sebagai komponen penilaian kinerja. Hal inilah yang menjadi penyebab orang yang bekerja sebagai Pegawai Negeri Sipil dan Karyawan lebih patuh.

Hasil penelitian ini sejalan dengan penelitian yang dilakukan oleh Pasaribu dan Tjen (2012). Penelitian tersebut menyimpulkan bahwa orang yang bekerja sebagai pegawai negeri sipil lebih patuh dibandingkan dengan wirausaha dalam pemenuhan kewajiban perpajakannya.

\section{SIMPULAN}

Berdasarkan hasil analisis dan pembahasan yang telah dilakukan pada bab sebelumnya, maka dapat ditarik kesimpulan bahwa sosialisasi perpajakan berpengaruh positif terhadap kepatuhan wajib pajak orang pribadi di Kantor Pelayanan Pajak Pratama Tabanan. Pemahaman prosedur perpajakan berpengaruh positif terhadap kepatuhan wajib pajak orang pribadi di Kantor Pelayanan Pajak Pratama Tabanan. Umur berpengaruh negatif terhadap kepatuhan wajib pajak orang pribadi di Kantor Pelayanan Pajak Pratama Tabanan. Jenis pekerjaan wirausaha berpengaruh negatif terhadap kepatuhan wajib pajak orang pribadi di Kantor Pelayanan Pajak Pratama Tabanan. 
Berdasarkan hasil penelitian dan simpulan yang telah diuraikan, maka dapat disampaikan beberapa yaitu kantor Pelayanan Pajak Pratama Tabanan diharapkan terus melakukan sosialisasi tentang peraturan perpajakan terbaru sehingga wajib pajak lebih memahami tentang peraturan perpajakan terkini dan dapat melaksanakan kewajiban perpajakan dengan lebih baik. Bagi penelitian selanjutnya, disarankan untuk menambah variabel lain yang tidak digunakan dalam penelitian ini, ataupun dengan memperluas ruang lingkup penelitian dengan menggunakan sampel dari Kantor Pelayanan Pajak lainnya yang dapat digunakan sebagai sampel.

\section{REFERENSI}

Adiasa, N. 2013. Pengaruh Pemahaman Peraturan Pajak Terhadap Kepatuhan Wajib Pajak dengan Moderating Preferensi Resiko. Accounting Analysis Journal. 2 (3): h: 345-352.

Ajzen, Icek. 2005. Attitudes, Personality, and Behavior. Berkshire: Open University Press.

Ajzen, I. 2006. The Theory of Planned Behavior. http:// people. umass. edu/ aizen /tpb.html. Diakses pada 10 Agustus 2017.

Al-Mamun, Abdullah, Harry Entebang, Shazali Abu Mansor, and Qaiser Rafique Yasser. 2014. The Impact of Demografic Factors on Tax Compliance Attitude and Behavior in Malaysia. Journal of Finance, Accounting and Management. 5(1): h: 109-124.

Amilin dan Fanny Yusronillah. 2009. Analisis Pengaruh Tingkat Pendidikan dan Jenis pekerjaan Wajib Pajak Terhadap Motivasi dalam Memenuhi Kewajiban Pajak. Jurnal Manajemen Keuangan.

Andreoni, J., B. Erard, and J. Feinstein. 1998. Tax Compliance. Journal of Economic Literature. 36 (2): h:818- 860.

Ardianto, Danny Ariesta Nur dan Isroah. 2013. Pengaruh Sosialisasi Perpajakan dan Pemahaman Prosedur Perpajakan terhadap Kepatuhan Wajib Pajak PBB. Jurnal Profita Uiversitas Negeri Yogyakarta. 
Badan Pusat Statistik. 2017. Statistik Indonesia - Statistical Yearbook of Indonesia. Jakarta: CV.Dharmaputra.

Devos, Ken. 2009. An Investigation Into Australian Personal Tax Evaders Their Atitudes Towards Compliance and The Penalties For Non. Compliance Revenue Law Journal. 19 (1): h: 155.

Gerald, Chau dan Patrick Leung. 2009. A Critical Review of Fischer Tax Compliance Model (A Research Syntesis). Journal of Accounting and Taxation. 1(2): h:34-40.

Ghozali, Imam. 2013. Aplikasi Analisis Multivariate dengan Program SPSS. Semarang: Badan Penerbit Universitas Diponegoro.

Hammar., S.C. Jagers and K. Nordblom. 2005. Tax Evasion and The Importance of Trust. Working Paper, Goteborg University.

Hardiningsih, Pancawati. 2011. Faktor-faktor yang Mempengaruhi Kemauan Membayar Pajak. Jurnal Dinamika Keuangan dan Perbankan. 3 (1): h:126-142.

Herryanto, Marisa dan Agus Arianto Toly. 2013. Pengaruh Kesadaran Wajib Pajak, Kegiatan Sosialisasi Perpajakan, dan Pemeriksaan Pajak terhadap Penerimaan Pajak Penghasilan di KPP Pratama Surabaya Sawahan. Tax \& Accounting Review. 1 (1): h:124-135.

Ilyas, Wirawan B., dan Richard Burton. 2010. Hukum Pajak Teori, Analisis, dan Perkembangannya. Jakarta: Salemba Empat.

Jackson, B.R and V.C Milliron. 1986. Tax Compliance Research: Findings, Problems, and Prospects. Journal of Accounting Literature. 5(1): h:125165.

James, Simon. and Clinton Alley. 2002. Tax Compliance, Self Assessment and Tax Administration. Journal of Finance and Management in Public Service. 2 (2): h:24-42.

Manurung, Surya. 2013. Kompleksitas Kepatuhan Pajak. http://www. pajak.go.id/ content/article/kompleksitas-kepatuhan-pajak. Diakses 15 Mei 2017.

Nicoleta. 2011. A Review of Factors for Tax Compliance.International Jounal of Economics and Business Administration.

Noviyanti, Siska. 2015. Pengaruh Kesadaran Wajib Pajak, Pengetahuan dan Pemahaman Peraturan Perpajakan, Kualitas Pelayanan dan Ketegasan Sanksi Perpajakan Terhadap Kepatuhan WPOP (Studi Kasus KPP Pratama Ilir Barat Palembang). Jurnal Akuntansi STIE MDP Palembang. 
Nurhayati, Nunung, Elly Halimatusadiah, dan Diamonalisa. 2015. Influence of Tax Officer Service Quality and Knowledge of Tax on Individual Taxpayer Compliance in Tax Office (KPP) Bojonagara Bandung. International Journal of Applied Research 2015; 1(8): h:805-809

Rahayu, Siti Kurnia. 2010. Perpajakan Teori dan Teknis Perhitungan. Yogyakarta : Graha Ilmu.

Resmi, Siti. 2009. Perpajakan Teori dan Kasus. Jakarta: Salemba Empat.

Resmi, Siti. 2011. Perpajakan Teori dan Kasus. Jakarta: Salemba Empat.

Sadiman, Arief S., Rahardjo., Anung Haryono., dan Rahardjito. 2010. Media Pendidikan. Jakarta: Raja Grapindo Persada.

Savitri, Enni dan Musfialdy 2016. The Effect of Taxpayer, Tax Socialization, Tax Pinalty, Compliency cost at Taxpayer Complience with service quality as mediating variable. Elsevier Procedia Social and behavior Sciences.

Sugiyono. 2014. Metode Penelitian Bisnis. Bandung: Alfabeta.

Susanto, Herry. 2012. Membangun Kesadaran dan Kepedulian Sukarela Wajib Pajak. http://www.pajak.go.id / content / membangun - kesadaran - dan kepedulian -sukarela-wajib-pajak. Diakses 15 Mei 2017.

Torgler, B. 2005. Tax Morale and direct Democracy. Europan Journal Of Political Economy. 21: h:525-531.

Tryana, Tiraada. 2013. Kesadaran Perpajakan, Sanksi Pajak, Sikap fiskus terhadap Kepatuhan WPOP di Kabupaten Minahasa Selatan. Jurnal Ekonomi, Manajemen, Bisnis dan Akuntansi.

Winerungan, Oktaviane Lidya. 2013. Sosialisasi Perpajakan, Pelayana Fiskus dan Sanksi Perpajakan Terhadap Kepatuhan WPOP di KPP Manado dan KPP Bitung. Jurnal Ekonomi, Manajemen, Bisnis dan Akuntansi. 1(3): h:966. 